\title{
COGNITIVE DYNAMICS OF STANCETAKING IN RISK DISCOURSE SITUATION
}

\author{
Valentyna Ushchyna \\ Lesya Ukrainka Eastern-European National University, Ukraine \\ uval@ukr.net
}

\begin{abstract}
This article studies the cognitive dynamics of stancetaking in the discourse situations associated with risky behaviour and perilous decisions. The objective of this work is to find out what linguistic and cognitive mechanisms are used by speech participants to conceptualise a discourse situation as a situation of risk, and analyse the ways the stances on the discussed problem (here, the risk of addicting to FACEBOOK, as well as other social networks) are taken by discourse partners under different circumstances and varying communicative conditions. The overall theoretical framework for the study synthesises socio-constructionist and sociocognitive approaches to discourse analysis of risk and stance. In the post-modernist model, speakers use discourse to construct versions of the world which are variable, functional and consequential. Gilles Fauconnier's mental spaces theory $(1994,1997)$ served a methodological tool for re-assembling the ways stances on risks are taken in discourse interaction. Risk-taking has always been an integral part of human behaviour. We are constantly forced to make decisions that lead us towards unknown or uncertain consequences that can be potentially hazardous or even life-threatening. The study shows that the field of risk-taking in everyday life is extremely wide, embracing a diverse range of spheres such as household activities, gambling, sports, finance, medicine, technology or politics. Because risk pervades such a substantial part of our lives, it can be claimed as one of the fundamental concepts of the human conceptual system, thus, cognitive mechanisms of risk conceptualisation, as well as the linguistic ways of discursive stancetaking on risk have been determined, analysed and described in the present research.
\end{abstract}

Keywords: risk discourse situations; risk-taking; linguistic and cognitive mechanisms; stance; stancetaking; discourse interaction.

\section{Introduction}

The notion of risk has become exceptionally prominent in political and social debate lately. Though risk-taking has always been an integral part of human behaviour, recently it has developed to a regular topic for discussion both in individual conversations and in public exchange. On the one hand, we face risks every day - crossing the road, smoking, or just using a mobile phone. On the other hand, risk is about defence of national security, natural resources, environment or human rights.

According to the hypothesis of this research, risk can be treated as one of the key concepts of human culture, thus being an important part of individual and social communication. Thus, the present work sets out the aim to shed light on the conceptualisation of risk in the English language and the ways the stances on risk are taken in English discourse situations. Achieving this aim presupposes fulfilling the following analytical tasks: outlining the cognitive frames of the discourse situation of risk, finding out and describing cognitive mechanisms of stancetaking on risk in such situation, where stancetaking is seen as decision-making.

A fundamental assumption of socio-constructionist view of discourse analysis, serving a general methodological basis of this work, is that language is inseparable from the processes of thinking and reasoning. It is constructive in the way people use language to construe their unique versions of the world using words that are culturally, ideologically and historically available to them and, consequentially, this relies on socially shared meanings (Billig, 2001).

\section{Defining Risk and Stance}

\section{Risk}

By the twentieth century risk was mainly the notion of insurance and statistics, playing a key role in the development of capitalism and entrepreneurship. In modern theories, risk is understood as being constructed by attributing (expected or observed) negative outcomes to decisions (Zinn, 2010, p. 106). The change in the nature of risk perception and risk communication at the beginning of the $21^{\text {st }}$ century has been explained as "the end of certainty" (Prigozhyn, 1997), caused by the transformation from modernity to late modernity or post-modernity - civilization processes inseparably connected with the contemporary societal attitude to risk (Giddens, 1991; Beck, 1999). Post-modernity is seen as "the end of certainty and the politics of difference" (Leonard, 1997, p. 12), which is characterised by cultural and social transformations, by global risks and uncertainty over the future.

Uncertainty and alternativity, danger and fear, an expectation of eventual harm or possible excitement are central to a "risk society", a term coined by German sociologist Ulrich Beck almost 20 years ago (Beck, 1999). The notion of "risk society" is closely linked to the concept of "security / insecurity", found in the works of Antony Giddens (1991). In the shift from "industrial society" to "risk society", the reflexive

Ushchyna, V. (2019). Cognitive dynamics of stancetaking in risk discourse situation. Advanced Education, 12, $142-149$. DOI: $10.20535 / 2410-8286.154380$ 
burden of handling risk and finding "security" in the contemporary world is placed upon the shoulders of an individual. Due to a constant need to make responsible choices, or take stances, the main "security threat" is to the identity of an individual and to the conditions of his / her existence, which is no longer supported by traditional institutions, but is constantly at risk.

Risk is a complex phenomenon which is increasingly recognised to be a highly politicised and valueladen phenomenon (Douglas, 1992). As Lupton (1999, p. 59) puts it: "Debates and conflicts over risk have begun to dominate public, political and private arenas". Because in the era of the Internet any individual decision on risk may have considerable social, political and economic ramifications world-wide, "the language of risk is likely to perform standardising and centralising role at the level of public debate" (Douglas, 1992, p. x).

According to John Adams (2007), there are three main kinds of risk, graphically presented on Fig. 1.

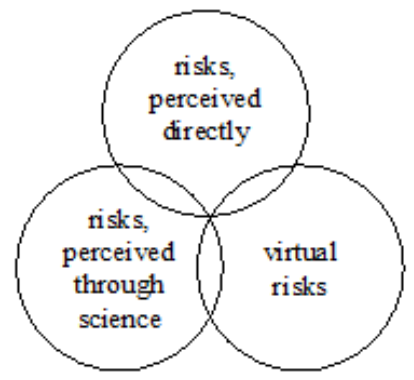

Fig. 1. Kinds of risk (Adams, 2007)

As is shown, all kinds of risks can be grouped into those which are (1) perceived directly (e.g., climbing a tree, riding a bike, bungee jumping, driving a car, etc.); (2) perceived through science (e.g., investigating cholera a scientist is aware of the risk of being infected); and (3) virtual risks such as global warming, lowlevel radiation, GMO food, mobile phones, etc.

While there is an ever-growing amount of literature on risk (Adams, 1995, p. 2), there are still few publications which cross the disciplinary boundaries of risk and language to take advantage of new developments in linguistics for the analysis of risk discourse situations (Ushchyna, 2018; Zinn, McDonald, 2018). Wyatt and Henwood (2006) argue for a shift to studying risk discourses in order to show how people draw on risk and construct risk in their speech.

Researchers in many disciplines have shown that speech behaviour in risk communication should be seen as a common product of intersubjective discussion of decisions on risk. However, understanding of the dynamics of interactive processes of risk perception and conceptualisation, as well as the dynamics of communication in risk discourse situations, remains under-developed. In this article, we examine the dynamic process of decision-making on risk, including RISK conceptualisation and further discourse stancetaking on risk.

\section{Stance}

The concept of stance-taking is approached here as an interactive and dynamic discursive phenomenon, which appears as the decision-making process in the risk situation.

The contextual conditions of the information era leave open various options for stance-takers' perceptual foci in their interpretations of risk. Awareness of the speakers' stances is necessary to take appropriate measures which aim to either remove real risks or to discard the virtual or false ones. As risk has no ontological status, and it is only our attitude that makes the situation "risky" or "non-risky", the notion of stancetaking acquires a special importance for researching human verbal behaviour associated with risk and decision-making.

In the last decades, the term stance has become extremely popular in literature related to discourse and communication (Du Bois, 2007, 2014; Du Bois \& Kärkkäinen, 2012; Englebretson, 2007; Jaffe, 2009; Kiesling, 2009; Kiesling et al., 2018). In most general terms stance is understood here as the way of expressing one's viewpoint concerning the object of interaction, which in this study is risk. Excitement, hope and fear are the parts of most risky situations. No one takes a risky decision (or, in other words, takes a stance on risk) without consulting his or her family, friends or colleagues, which brings us to the understanding of the importance of intersubjectivity in forming and formulating stances on risk. In other words, consensus-making or social influence on decisions become central to our investigation of stancetaking dynamics. Thus, the process of stance-taking is seen here as both a subjective (cognitive) and 
intersubjective (social) dynamic discursive phenomenon, linking micro- and macro-levels of discourse interaction.

\section{Research Hypothesis}

As risk is treated in this work as a subjective phenomenon, "positive" or "negative" connotations of risk interpretations depend upon the stances, taken by the communicative partners. Current forms of risk-taking behaviour, such as bungee jumping, taking psychoactive drugs, and reckless driving, cloning or Internet addiction are strikingly different from the risks our ancestors were facing in older times. Once upon a time, people needed to take a risk in order to find a shelter, food or defend their partner, whereas we, as members of "risk society", fairly often face virtual or invented (the so-called "man-made") risk.

We claim that during their stancetaking activities in the situation of risk interlocutors picture different possible ways of situation development, or, in other words, they construe various mental spaces related to the current contexts. On the basis of these mental spaces, they not only unfold complex cognitive operations simultaneously, but also take their decisions on risks. Thus, the dynamics of stancetaking in the situation of risk was analysed with the help of mental spaces (re)construction.

The ways we perceive risks and talk about them are directly connected to the notions of evidentiality (the source of information about risks) and modality, which, according to this study, form an epistemic stance. The ways we feel about risk are connected to our emotions and attitudes, which constitute an affective stance. Epistemic and affective stances are separated only for analytic purposes, otherwise they are inherently connected, as cognition and emotion operate as two distinct modes of reasoning to help individuals guide risk judgments and decisions.

Not only knowledge and cognition influence emotions, but emotions in return may also influence cognition. Our research shows that epistemic and affective stances are complementary and typically work in concert, but in certain circumstances, these modes of reasoning can diverge from one another.

\section{Data and Methods}

The data for this research were drawn from two types of sources: journalistic reviews of the Facebook risks and blogs, accessible via the Internet and following commentaries, revealing how risks are conceptualised through discourse stancetaking on-line). The data were gathered by searching for "risks of Facebook use" in the newspapers and blogs database search engine. The period of search includes August 2013 through August 2015.

FrameNet, based on a theory of meaning called Frame Semantics, deriving from the work of Fillmore et al (2003), offered its version of the RISK situation frame. This model served as a conceptual foundation for the analysis of stance, framed by the situational context of RISK.

Gilles Fauconnier's mental spaces theory $(1994,1997)$ served a methodological tool for re-assembling the ways stances on risks are taken in discourse interaction. Mental spaces theory focuses on people's cognitive operations in meaning construction. According to this theory, meaning construction refers to "the high-level, complex mental operations that apply within and across domains when we think, act, or communicate" (Fauconnier, 1997, p. 1). When people communicate, they constantly construct specific domains triggered by linguistic information and current contexts, by which they accomplish their stances construction and realise mutual communication. Fauconnier called such domains "mental spaces", referring to "small conceptual packets constructed as we think and talk, for purposes of local understanding and action" (Fauconnier \& Turner, 2002, p. 40).

Mental spaces theory (Fauconnier 1992, 1997) enabled us to express important generalisations about both epistemic and affective aspects of the speakers' discursive behaviour in the mentioned situational context.

\section{Results and Discussion}

\section{Conceptualisation of the discourse situation as a situation of Risk}

To investigate how participants of the risk discourse situations take their stances, we should, first of all, find out what one considers to be a situation of risk. How do people conceptualise discourse situations as situations of risk? In order to do that, two cognitive models of risk discourse situation were built, one of which is static (frame), while another one is dynamic (scenario).

Linguistic analysis of the phenomenology of risk has a multidisciplinary character and is realised in the paradigm of subjective tradition which allows the conceptualisation of this phenomenon as an important part of reality reflection by a subject. Image of an object or an event is rather a subjective attitude of an individual towards it than a reality. It also includes a motivational and evaluative positioning as well as a background 
assumption of a subject. Hence, the analysis was based on the ways of verbalising the concept of RISK in the English language, which allowed determining the content of its interpretive sphere.

FrameNet (https://framenet.icsi.berkeley.edu/fndrupal/) provided the knowledge basis needed to identify the RISK frame and semantic roles in the RISK situation. In frame semantics (Fillmore, 1982), a frame corresponds to a scenario that involves an interaction and its participants, where participants play some kinds of roles. Thus, based upon the FrameNet, a model of the situation of RISK was designed. Fillmore's RISK model was elaborated by introducing a meta-communicative element to it, which allowed not only to analyse the specific characteristics of the RISK situation, but also to align them with a broader social context.

At first, a list of lexical units nominating such a situation was created. The word risk served the basis for a search, as its semantic structure correlates with the conceptual nucleus of the RISK frame. Primary nominations of risk in English are seen as the verbal markers of the nuclear zone of this concept. They are not very numerous, but are represented by different parts of speech: a noun risk, a verb to risk, an adjective risky (its antonyms riskfree, riskless) and an adverb riskily. The number of nominations is growing due to taking into consideration the lexemes with similar meanings, the so-called "semantic neighbours" (Fillmore, 1992, p. 80): risk (n.) 1) chance, possibility; 2) danger, peril, jeopardy; 3) chance, hazard, uncertainty, speculation, venture; risk (v.) 1) put at risk, endanger, imperil, jeopardize; 2) take the risk of, chance, venture; inf. - grin and bear; 3) gamble, hazard, chance, venture; risky (adj.) dangerous, fraught with danger, hazardous, perilous, unsafe, precarious, touch-and-go, tricky, uncertain; inf. chancy, dodgy, dicey (OPT, p. 703).

Further usage of corpus analysis methodology for the analysis of the risk valence, its combinability and frequency as well as risk phraseology allowed defining the main ontological characteristics of RISK: uncertainty, probability, possibility, choice, chance, danger, loss, gain.

\section{The Risk Scenario}

The scheme for the risk scenario was borrowed from the Decision Taking Theory by American sociologists Amos Tversky and Daniel Kannemahn (1979), where risky choice presupposes a decision, treated here as a stance on risk (Fig. 2):

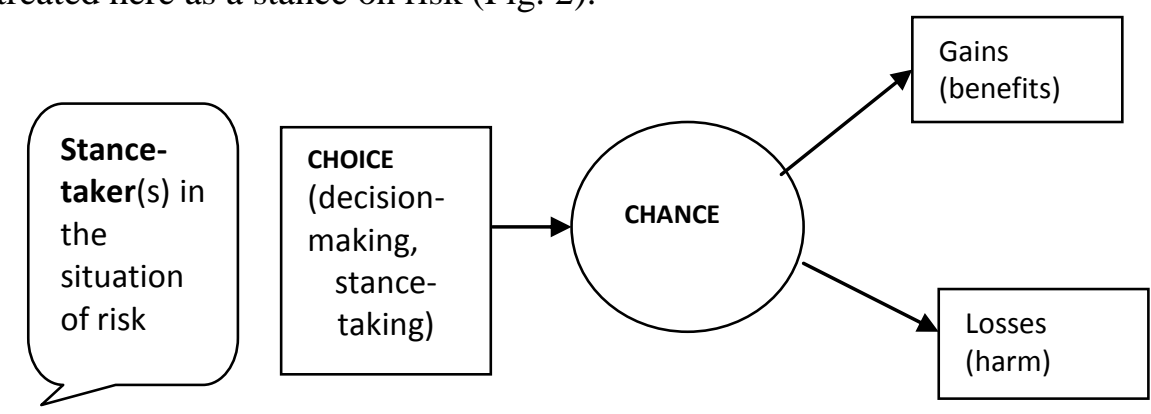

Fig.2. Stancetaking as Decision-making in a Risk Discourse Situation (Ushchyna, 2014, p. 221)

In a situation of risk, a stance-taker has to make a choice either in favour of risk or against it. If he/she chooses a pro-risk stance, then he/she receives a chance - either for gains and benefits or for losses or harm. As Luhmann (2005, p. 307) argues, "risks have to do with expectations, which can be more or less (un-) certain". Expectations are linked with knowledge and experiences (emotional included) of the past, and they can be developed to the representations of everyday knowledge and personal experiences (ibid.).

Having different expectations, subjects of the risk discourse situations base their differing stances on them. The process of stancetaking in this situational context is treated as the process of decision-making, with all the corresponding discourse actions and interactions.

\section{Decision-making in Risk Situations and Mental Spaces Construction}

In Fauconnier's words, "as discourse unfolds and mental spaces are set up, the recovery of meaning fundamentally depends on the capacity to induce shared structures, map them from space to space, and extend the mappings so that additional structure is induced and exported" (Fauconnier, 1996, p. 67). This view of meaning construction assumes the availability of various aspects of the interlocutors' knowledge at any stage of interpretation; knowledge that is structured by cognitive constructs of various types, be it frames, or scenarios.

Decision-making in the situation of risk involves a subjective conceptualisation of a scenario where some action should be taken and thus, the imagination of the possible results happens. Imagined futures constitute a basis for an important human activity - prediction and reasoning (Dancygier, 1998, p. 20). 
Prediction is seen here as the construction of different future scenarios (mental spaces) and then choosing the one which is more preferable than the other. On the basis of this choice, a decision on risk is taken and the discourse stance is manifested. Without engaging in prediction we would never be able to make decisions or take any actions in the situation of risk at all.

\section{Space-builders}

We begin with the idea that in the risk discourse situation, an if-clause or a when-clause set up mental spaces in Fauconnier's sense. In other words, a partial or local model of some aspect of mental content is constructed. In this case, a model of a discourse interaction in the risky situation or the process of stancetaking is built.

Thus, "if" and "when" are treated as "space-builders", which in Fauconnier's terms are the linguistic expressions, which set up different mental spaces in the flow of conversation (Fauconnier, 1992, p. 277).

In the risk discourse situation the space builders mainly fulfil the futuristic functions of alternativeness or prognosis, e.g.:

"But, if you are so busy in your virtual life that you forget about your real life, if you spend even more and more time online, and start to neglect yourself and the people around you - then, it is time that you started seriously thinking twice about Facebook".

The kind of space set up by if is hypothetical in the nature (Dancygier, 1998, p. 21). Thus, the job of "if" in the example is to prompt the set-up of hypothetical mental spaces.

Some decisions may be based on more certainty than others. They are expressed in an assertive epistemic stance. In saying "When you are on Facebook as much as people are today, you are bound to miss out on pretty much every epic thing happening in the world", the speaker does not consider mental spaces where the recipient does not spend time in the Facebook at all.

According to Fillmore $(1986,1990)$ "when" involves the speaker's commitment to "positive epistemic stance" (or assertive epistemic stance) towards the content (or the higher level of belief and assertiveness). While "if", unlike "when", seems to be indicating an uncertain positioning of the speaker with more possibilities of alternative hypothetical futures.

\section{Hypothetical Nature of the Risk Discourse Situation}

Let us assume that the situations of risk are of a hypothetical nature. The risk subjects can only picture eventual developing of the risk scenarios, based upon mental spaces construction. The idea of our ability to build mental spaces in the situation of risk gives us the opportunity to assume that we have some "real" space with which to contrast them. In fact, every speaker's reality space is different from every other person's one. However, although each speaker has some privileged set of mental spaces structures corresponding to his/her actual experience, there are some general, shared reality or base spaces, on which other constructed spaces depend.

$S_{1}$ : "As a matter of fact, Facebook is a very useful medium if used within certain limits"

$S_{2}$ : "It (Facebook) is quite distracting if not used within limits"

A basic mental space for both speakers in this situation presupposes that there is some kind of a phenomenon (namely, Facebook) that can be dangerous for them. Both of the stance-takers believe it can be addictive if you spend a lot of time on it. A predictive conditional "if" sets up a correlation of parameters which structure alternative mental spaces (see Fig. 3):

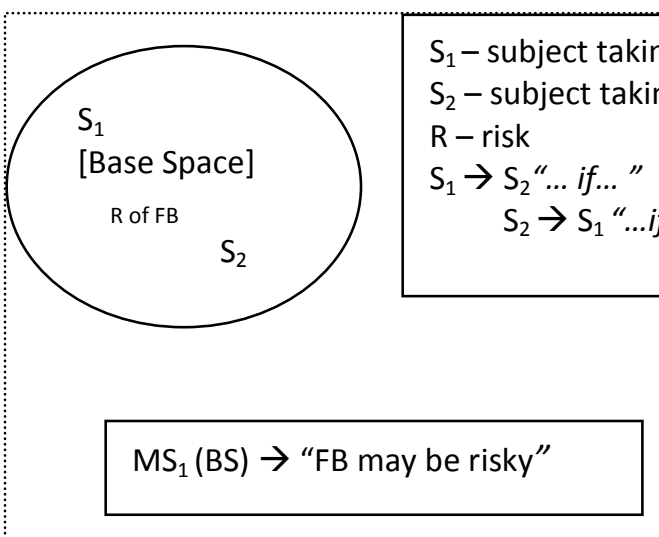

Fig. 3. Hypothetical Mental Space 
Space-builder "if" in these utterances represents two alternative mental-space set-ups, as shown in Figures 4 and 5, both interpreted as potential futures of the speakers' current base space. One contains information about the first speaker's (S1) positive stance towards Facebook "Facebook is a very useful medium...". An if-space sets up a hypothetical space (...if used within certain limits) which explains the attitude of a stance-taker towards the discussed risk object.

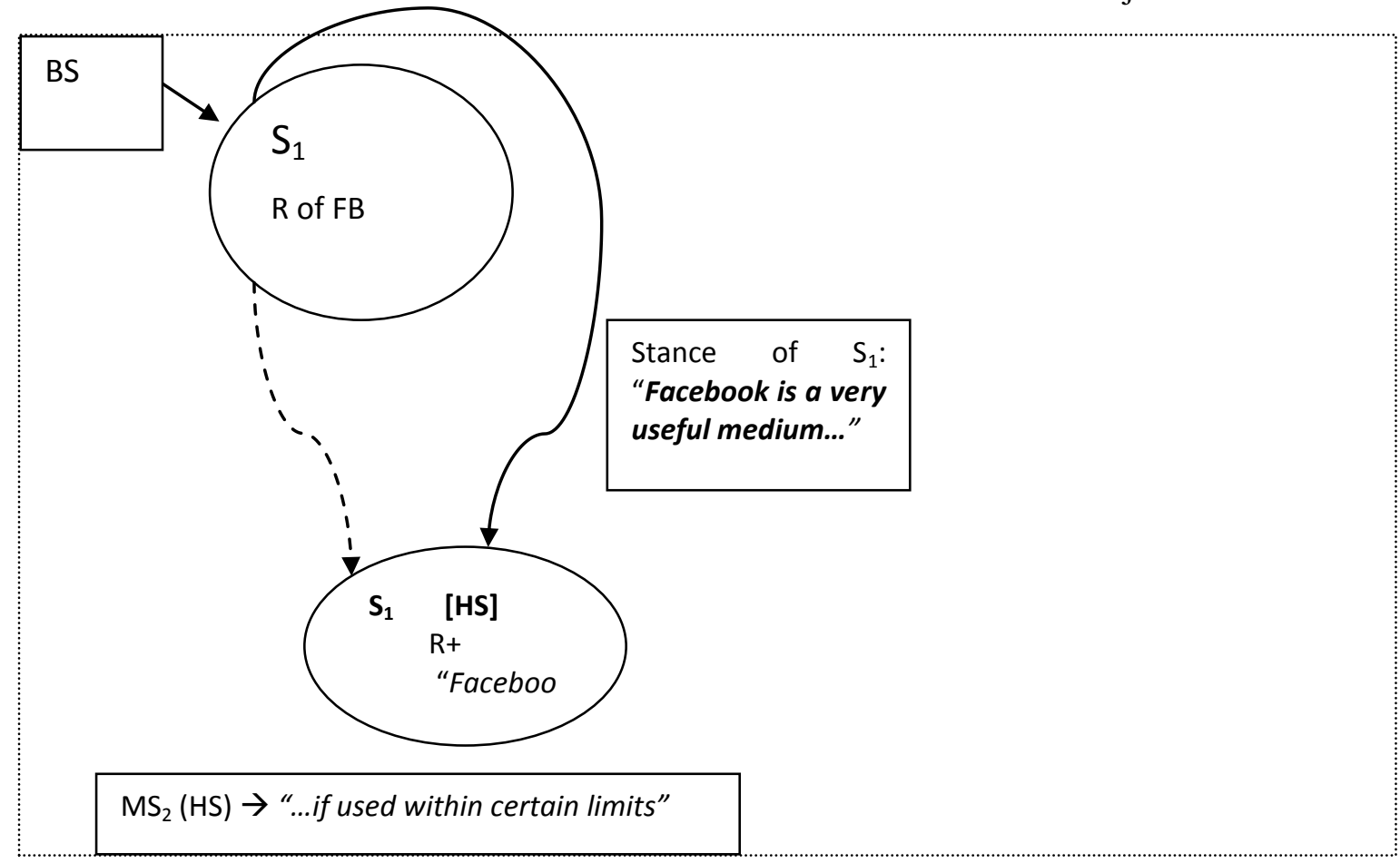

Fig. 4. Hypothetical Mental Space 2-1

The alternative mental space is set up by the other speaker (S2), whose negative stance towards Facebook is expressed in "It is quite distracting...". An if-space represents an alternative hypothetical future "... if not used within limits"

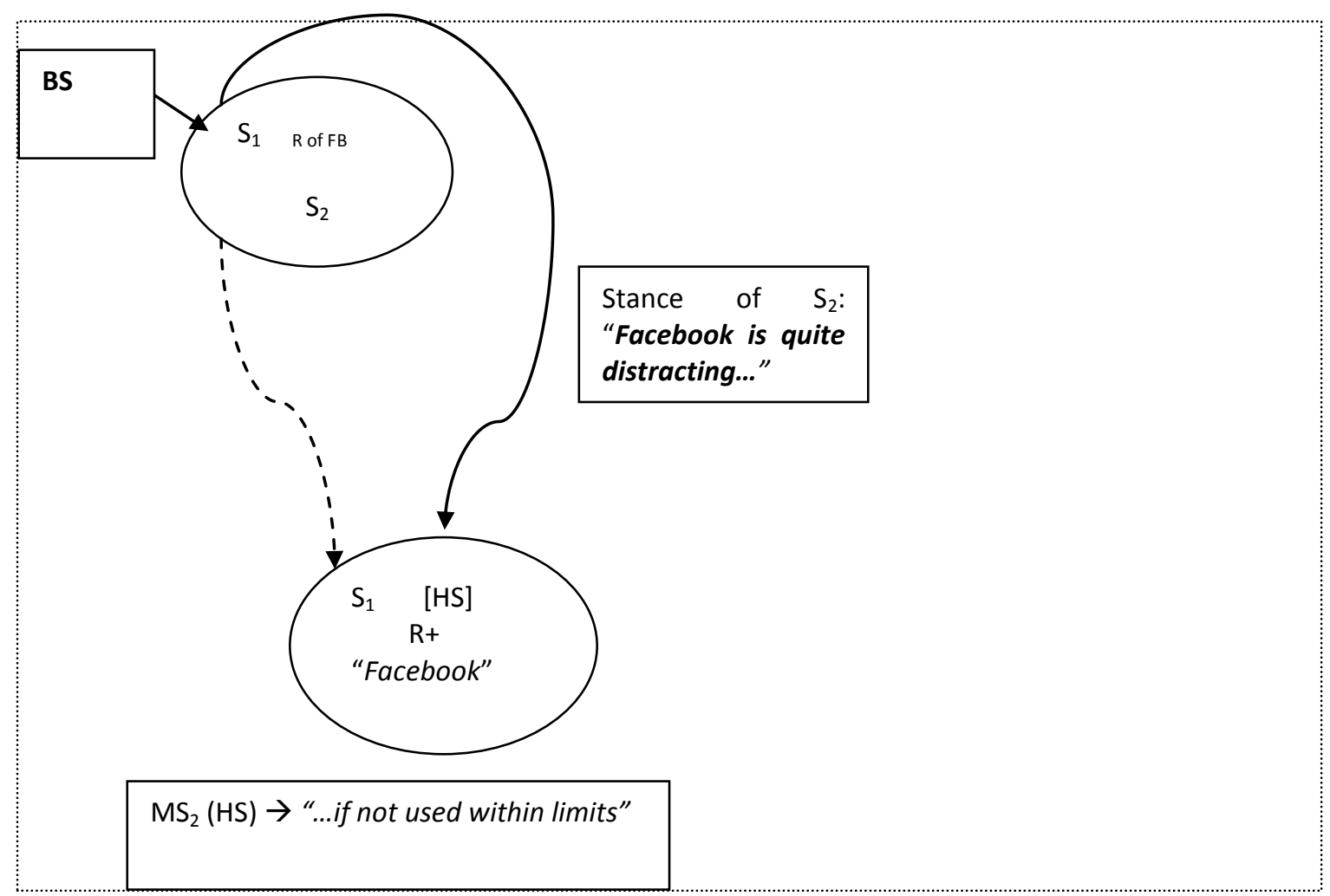

Fig. 5. Hypothetical Mental Space 2-2 
The essence of conditional predictiveness is the correlation (here: between the time spent on FB and the risks of getting addicted to it) which allows conditional prediction of one event based upon the knowledge about the other. Normally, speakers and hearers assume a causal structure behind such a correlation: that is, two events which are correlated strongly enough to permit prediction of one based upon knowledge about the other, are typically understood as correlated because of some causal relationships.

Thus, below a bi-conditional structure of predictions in the risk discourse situation as the basis for stancetaking is shown. In Fig. 6 the structure of stance-construction in the analysed situation is presented.

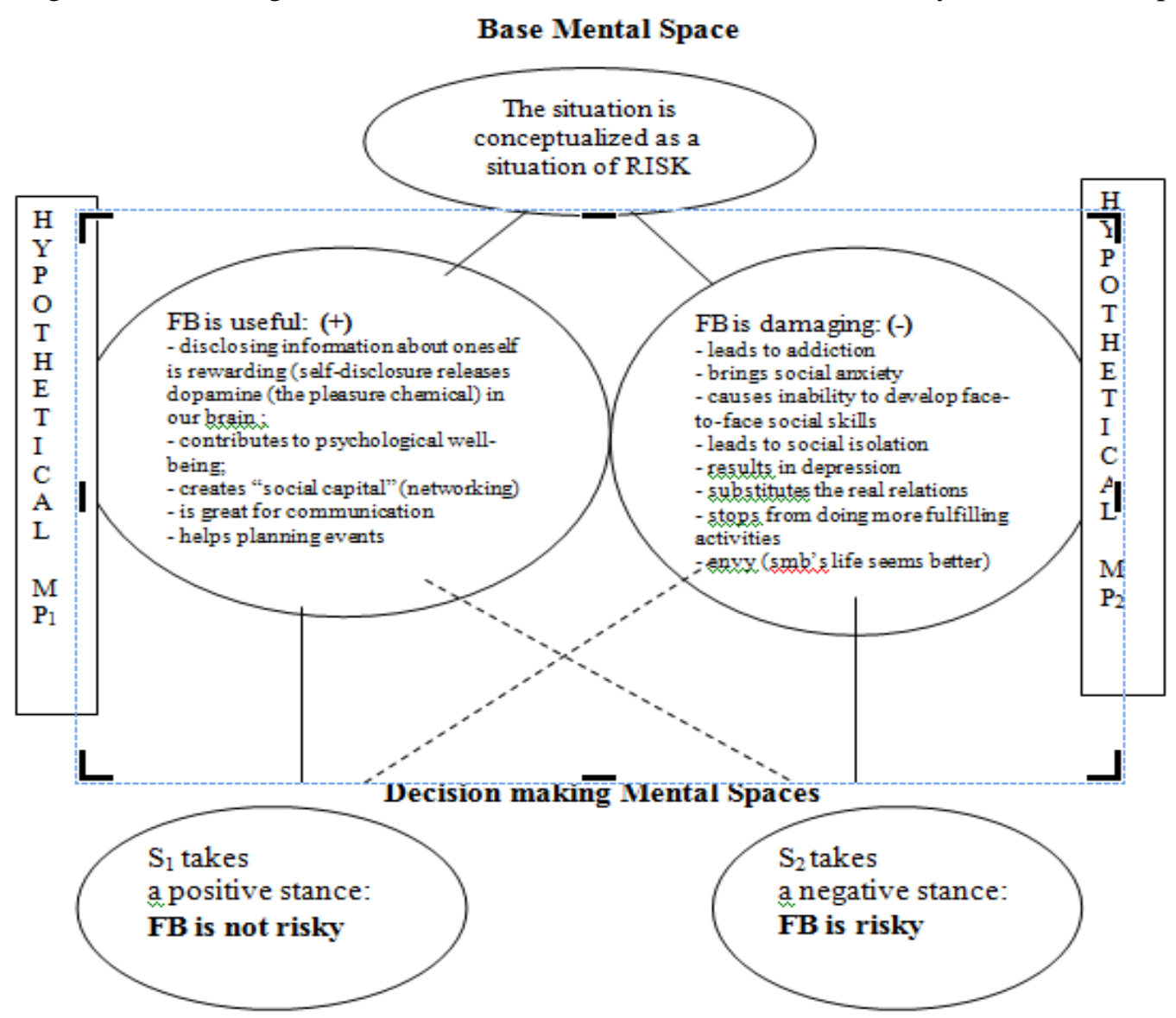

Fig. 6. Bi-conditional structure of stancetaking in the FB risk situation

We can now conclude that in the situation of risk predictive conditionals are normally interpreted as having double "iff" or bi-conditional structure. Every stance-subject is choosing simultaneously at least one out of two alternatives, building both pro- and against-risk hypothetical mental spaces. And then he / she chooses one of these alternatives grounding these choices on different emotional and rational information.

\section{Conclusions}

The analysis of stancetaking on risk in terms of mental spaces offered us the means to research the versatility of the risk discourse situation participants' behaviour in achieving their communicative goals. It also revealed the dynamics of the mental processes of reasoning which underlie their stancetaking performances.

In a discourse risk situation, the speaker's linguistic expressions set up spaces containing information about his / her epistemic and affective attitude comprising his/her discourse stance on a problem. The dynamic process of decision making (or: stance construction) in risk discourse has a bi-conditional structure, where different predictions of the possibilities of situation development are made, and consequently different mental spaces are built.

Researching discursive dynamics of stancetaking on risk within the framework of socio-cognitive and socio-constructionist approaches opens up opportunities for further interdisciplinary, integrative and problem-oriented models of discourse analysis, providing meaningful and transparent interpretations of text and talk. This work offers an instrument for explanation of systematic relations between linguistic manifestations and social phenomena, thus, allowing the research of interrelation between individual (cognitive) and collective (social) semiosis. 


\section{References:}

Adams, J. (1995). Risk. Abingdon: Routledge.

Adams, J. (2007). Complexity and uncertainty in a risk-averse society. Three framing devices for managing risk. Omega conference. London, 22 January, 2007. Retrieved from http://john-adams.co.uk/wp-content/uploads/2007/01/omegasummary.pdf

Beck, U. (1999). World Risk Society. London: Polity Press.

Billig, M. (2001). Discursive, rhetorical and ideological messages. In Margaret Whetherell, Stephanie Taylor \& Simeon J. Yates (Eds.), Discourse Theory and Practice: a Reader (pp. 210-221). London: Sage.

Dancygier, B. (1998). Conditionals and Prediction: Time Knowledge and Causation in Conditional Constructions. Cambridge: Cambridge University Press.

Douglas, M. (1992). Risk and blame: Essays in cultural theory. London: Routledge.

Du Bois, J. W. (2007). The stance triangle. In Robert Englebretson (Ed.), Stancetaking in Discourse (pp. 139-182). Amsterdam: John Benjamins.

Du Bois, J. W., \& Kärkkäinen E. (2012). Taking a Stance on Emotion: Affect, Sequence, and Intersubjectivity in Dialogic Interaction. Text and Talk, 32(4), 433-451. https://doi.org/10.1515/text-2012-0021

Du Bois, J.W. (2014). Towards a Dialogic Syntax. Cognitive Linguistics, 25(3), 359-410. https://doi.org/10.1515/cog-2014-0024

Englebretson, R. (Ed.) (2007). Stancetaking in Discourse: Subjectivity, Evaluation, Interaction. Amsterdam : John Benjamins.

Fauconnier, G. (1994). Mental Spaces. New York: Cambridge University Press.

Fauconnier, G. (1996). Analogical Counterfacts. In Gilles Fauconnier \& Eve Sweetser (Eds.), Space, Worlds, and Grammar (pp. $57-$ 90). Chicago: University of Chicago Press.

Fauconnier, G. (1997). Mappings in Thought and Language. Cambridge: Cambridge University Press.

Fauconnier, G., \& Turner M. (2002). The Way We Think: Conceptual Blending and the Minds Hidden Complexoties. New York: Basic Books.

Fillmore, Ch. J. (1982). Frame Semantics. In Linguistic Society of Korea (Ed.), Linguistics in the Morning Calm (pp. 111-138). Seoul: Hanshin.

Fillmore, Ch.J. (1986). Varieties of conditional sentences. Eastern States Conference on Linguistics, 3, 163-182.

Fillmore, C. (1990). Epistemic Stance and Grammatical Form in English Conditional Sentences. The 26th Regional Meeting of the Chicago Linguistic Society, 1, 137-161.

Fillmore, Ch. J. \& Atkins B. T. (1992). Toward a frame-based lexicon: the semantics of RISK and its neighbors. In Adrienne Lehrer \& Eva Feder Kittay (Eds), Frames, Fields and Contrasts (pp. 75-102). Hillsdale, NJ: Lawrence Erlbaum.

Fillmore, Ch. J., Johnson, Ch. R. \& Petruck, M.R.L. (2003). Background to Framenet. International Journal of Lexicography, 16 (3), 235-250.

Giddens, A. (1991). Modernity and Self-Identity. Self and society in the late modern age. Cambridge: Polity Press.

Jaffe, A. (2009). Introduction: the sociolinguistics of Stance. In Alexandra Jaffe (Ed.), Stance: Sociolinguistic Perspectives (pp. 3 28). Oxford: OUP.

Kiesling, S.F. (2009). Style as stance. In Alexandra Jaffe (Ed.), Stance: Sociolinguistic Perspectives (pp. 171-194). Oxford: Oxford University Press.

Kiesling, S.F., Pavalanathan U., Fitzpatrick J., Han, X. \& Eisenstein, J. (2018). Interactional Stancetaking in Online Forums. Computational Linguistics, 44(4), 1-57. https://doi.org/10.1162/coli_a_00334

Leonard, P. (1997). Postmodern Welfare. London: Sage.

Luhmann, N. (2005). Risk: A Sociological Theory (Communication and Social Order). New Brunswick (N.J.), London: Aldine Transaction.

Lupton, D. (1999). Risk. New York: Routledge.

Potter, J., \& Wetherell M. (1987). Discourse and Social Psychology: Beyond Attitudes and Behavior. London: Sage.

Prigozhyn, I. (1997) The End of Certainty. New York, London: The Free Press.

Ushchyna, V. (2014). Stancetaking in the discourse on risk: identities construed. In D. Glynn \& M. Sjölin (Eds.), A Subjectivity and Epistemicity. Corpus, discourse, and literary approaches to stance (pp. 215-237). Lund: Lund University Press.

Ushchyna, V. (2018). Manipulative use of RISK as a stance in political communication. Discourse and Society, 29 (2), $198-221$. https://doi.org/10.1177/0957926517734424

Zinn, J.O. (2010). Risk as Discourse: Interdisciplinary Perspectives. CADAAD (Critical Approaches to Discourse Analysis across Disciplines), 4 (2), 106-124. Retrieved January 28, 2019 from http://cadaad.net/files/journal/CADAAD2010_Zinn.pdf

Zinn, J. O., \& McDonald D. (2018). Risk in The New York Times (1987-2014). A corpus-based exploration of sociological theories. London: Palgrave Macmillan.

Wyatt, S., \& Henwood F. (2006). The best bones in the graveyard: Risky technologies and risks in knowledge. In Julie Anderson and Carsten Timmerman (Eds.), Devices and Designs: Medical innovation in historical perspective (pp. 231-248). Houndmills: Palgrave Macmillan. 